\title{
Anti-VEGF Monoclonal Antibody
}

National Cancer Institute

\section{Source}

National Cancer Institute. Anti-VEGF Monoclonal Antibody. NCI Thesaurus. Code C2496.

A monoclonal antibody directed ag ainst human Vascular Endothelial Growth Factor

(VEGF), a protein that stimulates angiogenesis, and prevents VEGF from binding to its receptors, causing inhibition of angiogenesis. $(\mathrm{NCl})$ 